\title{
Thoracic surgery worldwide
}

Starting in this series, the fournal of Thoracic Disease (FTD) is launching a new regular feature entitled "Thoracic Surgery Worldwide". The aim of this series is to showcase the status of thoracic surgery around the world.

Today, thoracic surgery is one of the most rapidly developing specialties in all of surgery-both technically and technologically. Spectacular advances in minimally invasive approaches, peri-operative care, and integration of surgery into multi-modality treatment of chest diseases have contributed to fantastic progress in surgical outcomes for patients. Elements such as uniportal surgery, elective segmentectomy, enhanced recovery programs, and adjuvant target therapy for early-stage lung cancer are no longer novelties. These and other developments are increasingly seen as key components of modern practice that mean patients undergoing chest operations nowadays may experience outcomes dramatically better than just a decade ago.

However, behind each of these innovations is a unique story of research and development. Behind each institute adapting a new technique or technology lies a different set of challenges. It is important to appreciate that Thoracic Surgeons around the world face very different circumstances when crafting or accessing such advances. Different countries and regions will have different areas in which they have excelled or accumulated particular experiences. They may also have different foci for clinical research or different priorities for service development. Appreciating how Thoracic Surgery advances have been made and assimilated in different parts of the world provides invaluable lessons for future progress.

The "Thoracic Surgery Worldwide" series aims to give readers an introduction to the current status and future directions of this specialty in various regions of the world. Each article in this important series will focus on one country of region, and will be authored by a thoracic surgeon recognized as a leader in the specialty in their own country or region. Readers may learn from the best practices of international peers, benchmark their own work, gain inspiration for research, see opportunities for training abroad, and better appreciate the proud progress our specialty has made worldwide.

\section{Acknowledgments}

Funding: None.

\section{Footnote}

Provenance and Peer Review: This article was commissioned by the editorial office, Fournal of Thoracic Disease, for the series "Thoracic Surgery Worldwide". The article did not undergo external peer review.

Conflicts of Interest: The author has completed the ICMJE uniform disclosure form (available at https://jtd.amegroups.com/ article/view/10.21037/jtd-2022-01/coif). The series "Thoracic Surgery Worldwide" was commissioned by the editorial office without any funding or sponsorship. ADLS served as the unpaid Guest Editor of the series and serves as an unpaid editorial board member of the fournal of Thoracic Disease. The author has no other conflicts of interest to declare.

Etbical Statement: The author is accountable for all aspects of the work in ensuring that questions related to the accuracy or integrity of any part of the work are appropriately investigated and resolved.

Open Access Statement: This is an Open Access article distributed in accordance with the Creative Commons AttributionNonCommercial-NoDerivs 4.0 International License (CC BY-NC-ND 4.0), which permits the non-commercial replication and distribution of the article with the strict proviso that no changes or edits are made and the original work is properly cited (including links to both the formal publication through the relevant DOI and the license). See: https://creativecommons.org/licenses/by-nc$\mathrm{nd} / 4.0 /$. 


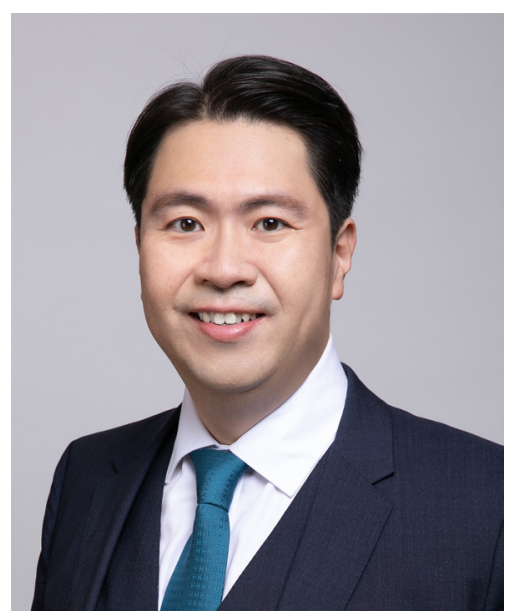

Alan D. L. Sihoe

Alan D. L. Sihoe, MBBChir, MA(Cantab), FRCSEd, FCSHK, FHKAM, FCCP, FACS

Honorary Consultant in Cardio-Thoracic Surgery, Gleneagles Hong Kong Hospital, Hong Kong, China. (Email: asiboe@gmail.com) Submitted Dec 29, 2021. Accepted for publication Jan 10, 2022. doi: $10.21037 /$ jtd-2022-01

View this article at: https://dx.doi.org/10.21037/jtd-2022-01

Cite this article as: Sihoe ADL. Thoracic surgery worldwide. J Thorac Dis 2022;14(1):216-217. doi: 10.21037/jtd-2022-01 